\title{
Dissipation Behaviour and Effect of Different Decontamination Processes on Reduction of Residues of Novaluron in Tomato (Lycopersicon esculentum Mill.)
}

\author{
Anita $^{1 *}$, V.K. Madan ${ }^{1}$, Reena Chauhan ${ }^{2}$ and Beena Kumari ${ }^{2}$ \\ ${ }^{1}$ Medicinal, Aromatic and Potential Crops Section, ${ }^{2}$ Department of Entomology, CCS \\ Haryana Agricultural University, Hisar-125004, Haryana, India \\ *Corresponding author
}

A B S T R A C T

\begin{tabular}{|l|}
\hline Ke y w o r d s \\
$\begin{array}{l}\text { Novaluron, Dissipation, } \\
\text { Half-life period, Tomato } \\
\text { fruits, Household } \\
\text { processing, GLC }\end{array}$ \\
\hline Article Info \\
\hline $\begin{array}{l}\text { Accepted: } \\
\text { 07 April } 2018 \\
\text { Available Online: } \\
\text { 10 May } 2018\end{array}$ \\
\hline
\end{tabular}

\section{Introduction}

Pesticides are chemical compounds which are biologically active and used worldwide for the protection of crops, fiber and human health (Malhat et al., 2015). These pesticides tend to degrade after application with their residues remaining not only in the plants but also in various environmental matrices, like water, soil or sediments. Humans main exposure route is via food that contribute five times more than other routes, such as air and drinking water (Claeys et al., 2011; Malhat et al., 2014b). Tomato (Lycopersicon esculentum Mill.) is the world's largest vegetable crop after potato and sweet potato, but it tops the list of canned vegetables (Ganesan et al., 2012). In India tomato is grown over an area of 125,000 hectares, where climate conditions are such that the tomato can be cultivated in any month of the year (NHB 2015). The tomato crop is infested by jassids, aphids, tobacco caterpillar, flea beetles, leaf miner, spider mites and fruit borer (Thamburaj and Singh 2015). Hence, in order to combat the insect pest problem, lots of pesticides are used by the vegetable growers. Insecticide growth regulator (IGR) is the class of pesticide used to control pest species by mostly targeting juveniles rather than adults. Primarily, IGR's 
inhibit the development of target species by acting as chitin synthesis inhibitors, ecdysone agonists and juvenile hormone mimics (reviewed by Tasei, 2001). IGR's do not typically exhibit acute effects on adult bees and numerous IGR's including the chitin synthesis inhibitors novaluron and diflubenzuron and ecdysone agonist methoxyfenozide are registered as 'reduced risk' pesticides in various crops (USEPA, 2017).

It was reported by Das et al., (2008) that Novaluron [( \pm -1-[3-chloro-4-(1,1,2-trifluoro2-rifluoromethoxyethoxy)- phenyl]-3-(2,6difluoro-benzoyl)urea], is a relatively new benzoylphenyl urea insect growth regulator which inhibits the chitin formation on larvae of various insects (Lepidoptera, Coleoptera, Homoptera and Diptera). Insect growth regulators (IGR) insecticides are comparatively safer to beneficial insects and environment and are compatible for use in an integrated pest management system. This compound is coming up as an eco-friendly or green pest-controlling agent. The detailed studies of novaluron have not been undertaken so far on tomato fruits especially in Haryana state. Besides this, information on reduction of residues of novaluron in tomato fruits by kitchen processes like unwashed, washing, boiling, peeling is also lacking. Thus, keeping this in view, the present investigation was undertaken to study the dissipation of novaluron residues and effect of different decontamination processes on reduction of residues in tomato fruits.

\section{Materials and Methods}

\section{Field experiment}

Experiment was conducted at Research Farm of Department of Entomology, CCS HAU, Hisar in randomized block design (RBD) plots as per good agricultural practice (GAP) in the month of May, 2015. Novaluron was applied in the field on the tomato crop (variety HS-86) at $50 \%$ fruiting stage with Knapsack sprayer in plots of size $16 \mathrm{~m}^{2}$. Two doses of novaluron were used, for single dose $43.31 \mathrm{~g}$ a.i. ha ${ }^{-1}$ and for double dose $86.62 \mathrm{~g}$ a.i. ha $^{-1}$ was applied, where as one plot was left untreated and used for the sampling of fruits as control in each treatment. About $1 \mathrm{~kg}$ of tomato sample was collected randomly and separately from the control and treated plots of each treatment at 0 $(1 \mathrm{~h}), 1,3,5,7,10$ and 15 days after the application of the insecticide. The samples from each treated plot were collected periodically from each plot separately and subjected to household processing like washing, washing followed by boiling/cooking and peeling as explained below. Residues from processed samples were extracted, cleaned and analyzed by gas liquid chromatography (GLC). Residues status was compared with control.

\section{Extraction and clean-up}

Tomato fruits samples collected from field were chopped and macerated in Warring blender to make a fine paste. Representative $20 \mathrm{~g}$ of tomato sample were extracted in acetone. Then filtered extract was partitioned thrice with dichloromethane and hexane (75, $50,25 \mathrm{ml}$ ) by vigorous shaking for $5 \mathrm{~min}$ to remove the non-emulsifying impurities. Each time, organic phase was collected and pooled organic layer was concentrated to $5 \mathrm{ml}$ on Rotary Vacuum Flask Evaporator. For cleanup of extract, adsorbent mixture i.e. silica + activated charcoal $(5+0.2 \mathrm{w} / \mathrm{w})$ was used as per method of Gupta et al., (2011). The final volume was concentrated and made upto $5 \mathrm{ml}$ in acetone for GC analysis.

\section{Instrumentation}

The residues of novaluron were estimated using gas liquid chromatography (Shimadzu 
GC-2010) equipped with a fused silica capillary column, Restek -1(30 m x $0.32 \mathrm{~mm}$ i.d. $\mathrm{x} 0.25 \mu \mathrm{m}$ film thickness) of $5 \%$ diphenyl $+95 \%$ dimethyl polysiloxane and electron capture detector (ECD).

The operating GC parameters were: injector temperature: $280^{\circ} \mathrm{C}$, detector temperature: $300^{\circ} \mathrm{C}$ and oven temperature programe was 150 (5min) increased at $8^{0} \mathrm{C} \mathrm{min}^{-1}$ up to 190 (2min) further increased at $15^{0} \mathrm{C} \mathrm{min}{ }^{-1}$ up to $280^{\circ}$ (5 min) with split ratio $1: 10$. Total gas flow rate was $60 \mathrm{ml} \mathrm{min}{ }^{-1}$. Retention time $\left(\mathrm{R}_{\mathrm{t}}\right)$ for novaluron was 2.329 minute.

\section{Limit of detection and quantification}

Residues of novaluron were determined by comparing the peak areas of the reference standards with those of the unknown or spiked samples run under identical working conditions of the instruments employed (Table 1 and Figure 1).

For novaluron half-scale deflection was obtained for $0.5 \mu \mathrm{g} \mathrm{ml}^{-1}$, which could be easily identified from the baseline as $0.1 \mu \mathrm{g} \mathrm{ml}^{-1}$ of the compound produced $10 \%$ deflection, which can be measured. When $1 \mu \mathrm{L}(5 \mathrm{mg})$ of the sample was injected then did not produce any background interference. Thus, the limit of quantification (LOQ) was found to be 0.01 $\mathrm{mg} \mathrm{kg}$ and the limit of detection (LOD) observed to be $0.005 \mathrm{mg} \mathrm{kg}^{-1}$ for tomato fruits.

\section{Recovery}

Representative $20 \mathrm{~g}$ of chopped tomato fruits were taken in $250 \mathrm{ml}$ Erlenmeyer flasks and were fortified @ 0.01 to $0.25 \mathrm{mg} \mathrm{kg}^{-1}$ with standard pesticides. As evident from data given in Table 2, average recoveries from samples of tomato fruits fortified at $0.01,0.10$ and $0.25 \mathrm{mg} \mathrm{kg}^{-1}$ levels were $82.20,87.35$ and 89.47 per cent of novaluron.

\section{Results and Discussion}

\section{Persistence and dissipation kinetics of novaluron}

As clear from experimental data (Table 3), the application of (novaluron 5.25\% SC) at single dose $\left(\mathrm{T}_{1}\right)$ consisted of $825 \mathrm{~g} \mathrm{ha}^{-1}$ (equivalent to $43.31 \mathrm{~g}$ a.i. $\left.\mathrm{ha}^{-1}\right)$ and the double dose $\left(\mathrm{T}_{2}\right)$ consisted of $1650 \mathrm{~g} \mathrm{ha}^{-1}$ (equivalent to $86.62 \mathrm{~g}$ a.i. $\mathrm{ha}^{-1}$ ) of insecticide on tomato fruits in field conditions resulted an initial deposits in tomato fruits to the extent of 0.30 and $0.56 \mathrm{mg}$ $\mathrm{kg}^{-1}$ at single and double dose in novaluron, respectively. The residues of novaluron dissipated with time gradually after application in both the doses. At single dose, residues of novaluron reached below MRL value of $0.01 \mathrm{mg} \mathrm{kg}^{-1}$ on $7^{\text {th }}$ day and at double dose it was below MRL on $10^{\text {th }}$ day. Regression equations, half-life values and correlation coefficient of novaluron have also been shown in Table 3 and plot of $\log$ [Residues ( $\mathrm{mg} \mathrm{kg}^{-1}$ ) x 10 ${ }^{3}$ ] and time (in days) were also plotted to study the degradation kinetics of novaluron residues in tomato fruits (Fig. 2). The residues half-life values for novaluron were 1.40 days and 1.52 days at single and double dose, respectively following first order kinetics. The values of correlation coefficient for degradation kinetics in tomato fruits were 0.849 and 0.968 for single and double dose of novaluron in tomato fruits. The results of novaluron were in agreement with those of Malhat et al., (2014a) who studied the dissipation behaviour of novaluron. The method was validated using blank samples spiked at three levels and results showed that recoveries ranged from 93 to $99 \%$. The initial concentration of novaluron residues in tomato was $0.51 \mathrm{mg} / \mathrm{kg}$ which dissipated following first-order rate kinetics with half-life of 2.08 days. Das et al., (2007) noted that residues of novaluron rapidly dissipated in chili and brinjal following first-order reaction kinetics at all rates of application with half-lives of 
1.80 to 1.95 days (for chili) and 1.8 to 2.08 days (for brinjal), respectively.

\section{Decontamination studies}

Food processing techniques are the set of methods and unit operations used to transform raw ingredient into edible form for direct consumption either in the home or by the food processing industry (Tomer and Sangha 2013).

In present investigation when the samples were subjected to washing with simple tap water than residues of novaluron tend to decrease with increase in time duration. Higher per cent reduction was recorded in double dose as compared to single dose on 0 day ( $1 \mathrm{~h}$ after treatment). The data presented in
Table 4 and 5 revealed that at single dose after washing treatment residues reduced to 0.24 and $0.09 \mathrm{mg} \mathrm{kg}^{-1}$, after 0 and 1 days, respectively resulting in 20.00 and 10.00 per cent reduction due to washing on 0 (1h after spray) and 1 day after treatment. However, when, sample was subjected to washing + boiling, initial residue level reduced to 0.13 , 0.04 and $0.02 \mathrm{mg} \mathrm{kg}^{-1}$ on 0 ( $1 \mathrm{~h}$ after spray), 1 and 3 days after treatment in tomato fruits resulting in 56.66, 60.00 and 66.66 per cent reduction respectively. When sample were subjected to peeling, residue level reduced to $0.06,0.03$ and $0.03 \mathrm{mg} \mathrm{kg}^{-1}$ on 0 ( $1 \mathrm{~h}$ after spray), 1 and 3 days after treatment resulting in $80.00,70.00$ and 50.00 per cent reduction. After $5^{\text {th }}$ day residues were below detectable level of $0.01 \mathrm{mg} \mathrm{kg}^{-1}$ as shown in figure 3 .

Table.1 Standard curve data of novaluron

\begin{tabular}{|c|c|}
\hline Amount (ng) & Area of novaluron \\
\hline 0.01 & 2050 \\
\hline 0.025 & 4260 \\
\hline 0.10 & 14985 \\
\hline 0.25 & 33905 \\
\hline 0.50 & 98405 \\
\hline 1.00 & 192830 \\
\hline
\end{tabular}

Table.2 Per cent recovery of novaluron from tomato fruits

\begin{tabular}{|c|c|}
\hline $\begin{array}{c}\text { Fortification Levels } \\
\left(\mathrm{mg} \mathrm{kg}^{-1}\right)\end{array}$ & $\begin{array}{c}\text { Novaluron } \\
\text { Average Recovery* } \%) \pm \mathrm{SD}\end{array}$ \\
\hline 0.01 & $82.20 \pm 1.71$ \\
\hline 0.10 & $87.35 \pm 4.38$ \\
\hline 0.25 & $89.47 \pm 2.32$ \\
\hline
\end{tabular}

*Average of three replicates 
Table.3 Residues $\left(\mathrm{mg} \mathrm{kg}^{-1}\right.$ ) of novaluron in tomato fruits

\begin{tabular}{|c|c|c|c|c|c|}
\hline \multirow{3}{*}{$\begin{array}{l}\text { Days } \\
\text { after } \\
\text { treatment }\end{array}$} & \multicolumn{4}{|c|}{ Novaluron residues ( $\mathrm{mg} \mathrm{kg}^{-1}$ ) } & \multirow[t]{3}{*}{ Mear } \\
\hline & \multicolumn{2}{|c|}{$T_{1}\left(43.31\right.$ g a.i. ha $\left.{ }^{-1}\right)$} & \multicolumn{2}{|c|}{$T_{2}\left(86.62\right.$ g a.i. ha $\left.^{-1}\right)$} & \\
\hline & $\begin{array}{c}\text { Average } \\
\text { residues* } \pm \text { SD }\end{array}$ & \% Dissipation & $\begin{array}{c}\text { Average } \\
\text { residues* } \pm \text { SD }\end{array}$ & $\begin{array}{c}\% \\
\text { Dissipation }\end{array}$ & \\
\hline $\mathbf{0}$ & $0.30 \pm 0.02$ & - & $0.56 \pm 0.04$ & - & 0.43 \\
\hline 1 & $0.10 \pm 0.01$ & 66.66 & $0.23 \pm 0.03$ & 58.92 & 0.17 \\
\hline 3 & $0.06 \pm 0.01$ & 80.00 & $0.11 \pm 0.03$ & 80.35 & 0.09 \\
\hline 5 & $0.01 \pm 0.004$ & 96.66 & $0.05 \pm 0.02$ & 91.07 & 0.03 \\
\hline 7 & BDL & 100.00 & $0.01 \pm 0.003$ & 98.21 & 0.01 \\
\hline 10 & - & - & BDL & 100.00 & \\
\hline 15 & - & - & - & - & \\
\hline \multirow[t]{2}{*}{ Mean } & 0.12 & & 0.19 & & \\
\hline & \multicolumn{2}{|c|}{$\begin{array}{l}\text { Correlation coefficient } R^{2}=0.849 \\
\text { Regression equation } y=-0.215 x+1.372 \\
t_{1 / 2}=1.40 \text { days }\end{array}$} & \multicolumn{2}{|c|}{$\begin{array}{l}\text { Correlation coefficient } R^{2}=0.968 \\
\text { Regression equation } y=-0.198 x+1.659 \\
t_{1 / 2}=1.52 \text { days }\end{array}$} & \\
\hline
\end{tabular}

For regression equation [residues $\left.\left(\mathrm{mg} \mathrm{kg}^{-1}\right) \times 10^{3}\right]$ is taken

*Average residues \pm SD of three replicates; Below detectable level (BDL): $0.01 \mathrm{mg} \mathrm{kg}^{-1}$

Table.4 Effect of processing on reduction of novaluron residues in tomato fruits at single dose

\begin{tabular}{c|c|c|c|c|}
$\begin{array}{c}\text { Days } \\
\text { after } \\
\text { treatment }\end{array}$ & $\begin{array}{c}\text { Novaluron residues }\left(\mathrm{mg} \mathrm{kg}^{-1}\right) \\
\text { Average residues* } \\
\text { SD }\left(\mathbf{m g ~ k g}^{-1}\right)\end{array}$ & Washing & Washing + Boiling & Peeling \\
\hline $\mathbf{0}$ & $0.30 \pm 0.02$ & $0.24 \pm 0.04(20.00)$ & $0.13 \pm 0.01(56.66)$ & $\mathbf{0 . 0 6} \pm \mathbf{0 . 0 3}(\mathbf{8 0 . 0 0})$ \\
\hline $\mathbf{1}$ & $0.10 \pm 0.005$ & $0.09 \pm 0.01(10.00)$ & $0.04 \pm 0.03(60.00)$ & $\mathbf{0 . 0 3} \pm \mathbf{0 . 0 1}(\mathbf{7 0 . 0 0})$ \\
\hline $\mathbf{3}$ & $0.06 \pm 0.01$ & BDL & $0.02 \pm 0.005(66.66)$ & $\mathbf{0 . 0 3} \pm \mathbf{0 . 0 2}(\mathbf{5 0 . 0 0})$ \\
\hline $\mathbf{5}$ & $0.01 \pm 0.004$ & - & BDL & BDL \\
\hline $\mathbf{7}$ & BDL & - & - & - \\
\hline 10 & - & - & - & - \\
\hline 15 & - & - & - & - \\
\hline
\end{tabular}

*Average residues $\pm \mathrm{SD}$ of three replicates

Figures in parenthesis is per cent reduction of residues

Table.5 Effect of processing on reduction of novaluron residues in tomato fruits at double dose

\begin{tabular}{|c|c|c|c|c|}
\hline \multirow{2}{*}{$\begin{array}{c}\text { Days } \\
\text { after } \\
\text { treatment }\end{array}$} & \multicolumn{4}{|c|}{ Novaluron residues $\left(\mathrm{mg} \mathrm{kg}^{-1}\right)$ at $T_{2}\left(86.62 \mathrm{~g}\right.$ a.i. ha $\left.{ }^{-1}\right)$ double dose } \\
\hline & $\begin{array}{l}\text { Average residues* } \pm \\
\text { SD }\left(\mathrm{mg} \mathrm{kg}^{-1}\right)\end{array}$ & Washing & Washing + Boiling & Peeling \\
\hline $\mathbf{0}$ & $0.56 \pm 0.04$ & $0.43 \pm 0.04(23.21)$ & $0.22 \pm 0.03(60.71)$ & $0.09 \pm 0.04(80.00)$ \\
\hline 1 & $0.23 \pm 0.03$ & $0.20 \pm 0.05(13.04)$ & $0.07 \pm 0.02(69.56)$ & $0.05 \pm 0.03(78.26)$ \\
\hline 3 & $0.11 \pm 0.03$ & $0.10 \pm 0.02(9.09)$ & $0.03 \pm 0.01(72.72)$ & $0.04 \pm 0.02(63.63)$ \\
\hline 5 & $0.05 \pm 0.02$ & BDL & BDL & BDL \\
\hline 7 & $0.01 \pm 0.003$ & - & - & - \\
\hline 10 & BDL & - & - & - \\
\hline 15 & - & - & - & - \\
\hline
\end{tabular}

*Average residues $\pm \mathrm{SD}$ of three replicates

Figures in parenthesis is per cent reduction of residues 
Fig.1 Standard curve of novaluron

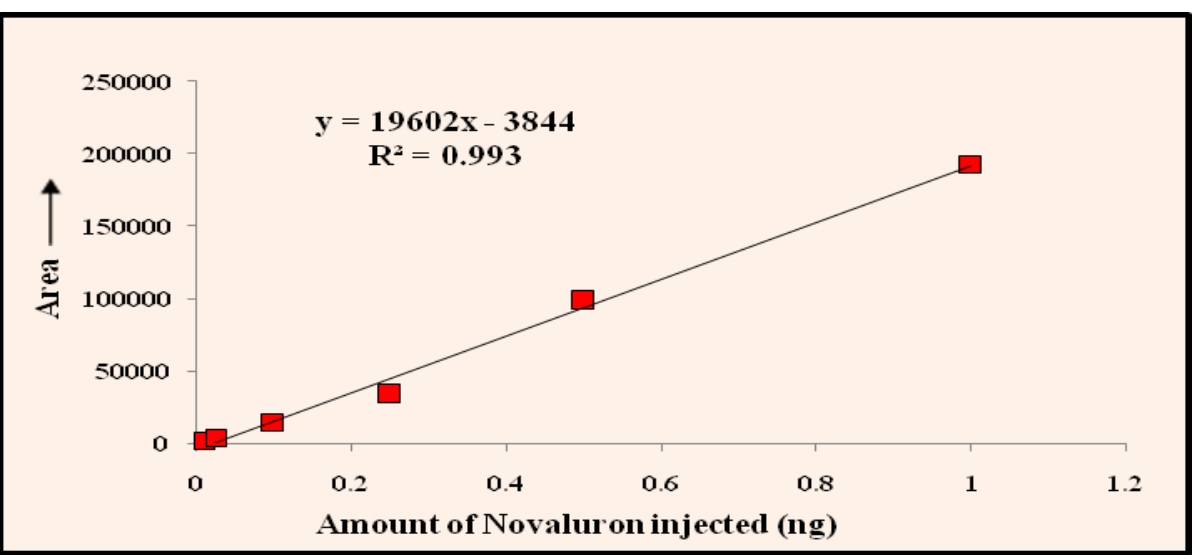

Fig.2 Semi Logarithm graph showing dissipation kinetics of novaluron in tomato fruits

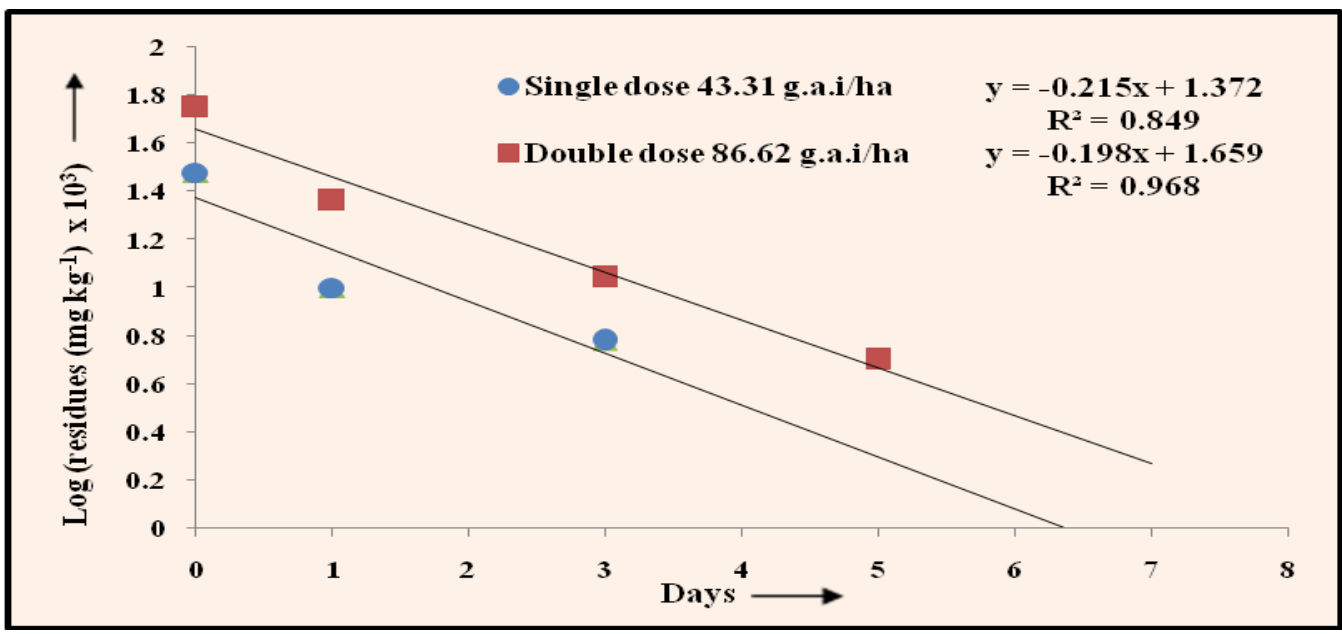

Fig.3 Effect of processing on reduction of residues of Novaluron in tomato fruits at single dose

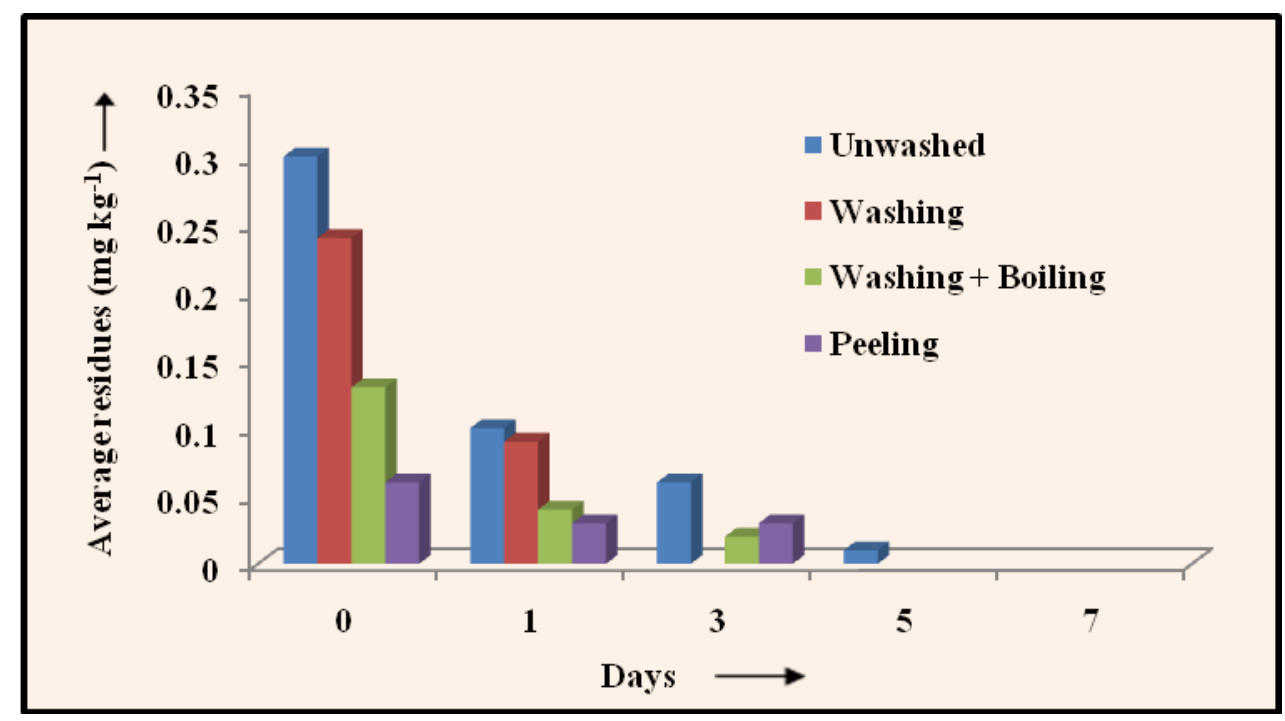




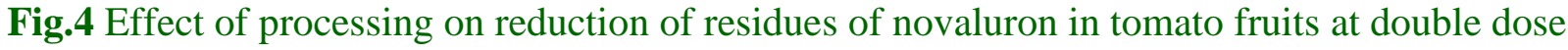

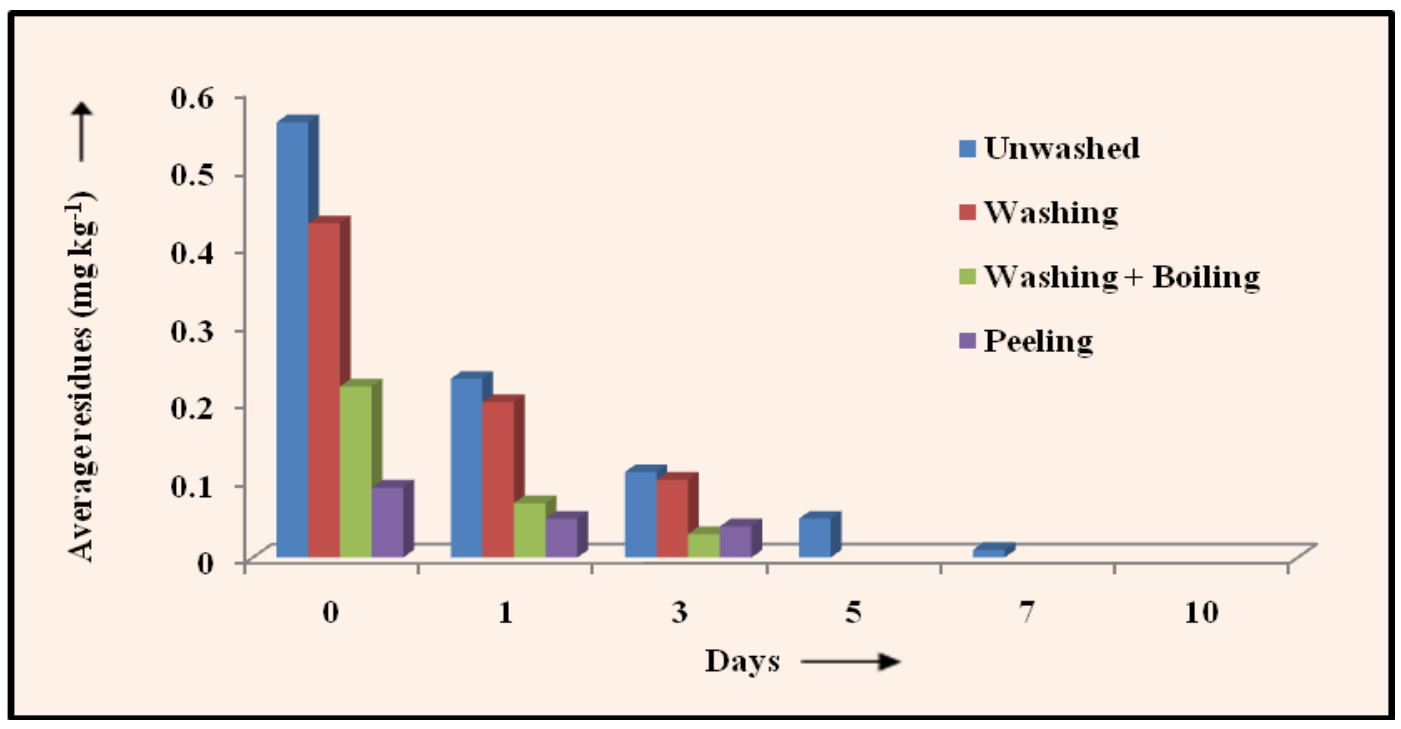

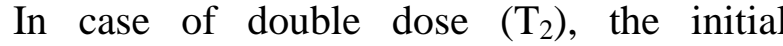

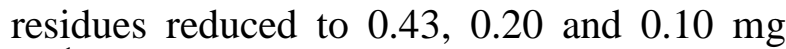

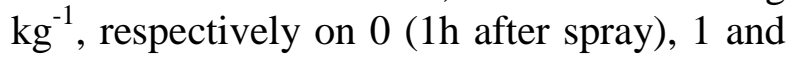

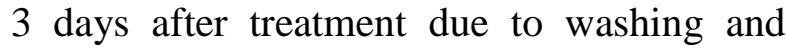

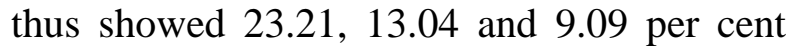

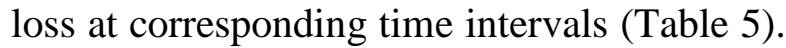

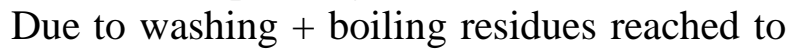

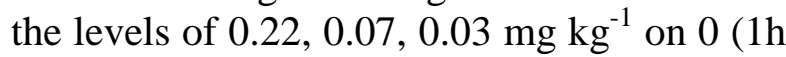

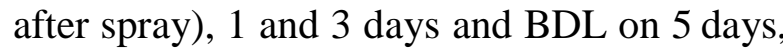

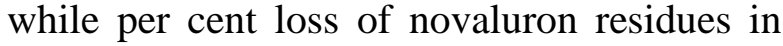

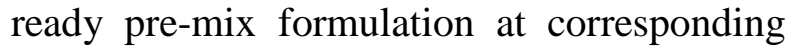

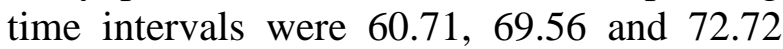

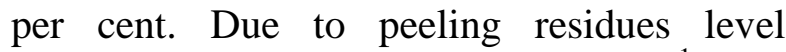

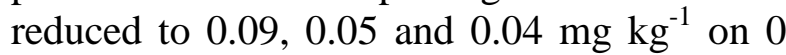

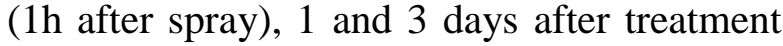

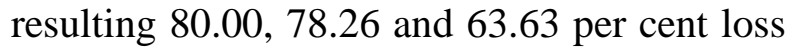

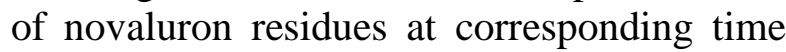

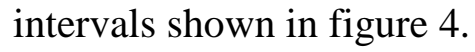

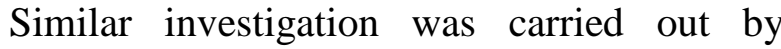

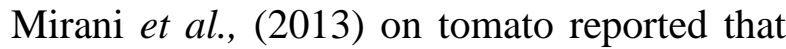

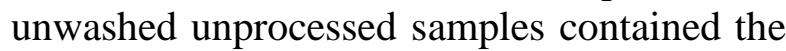

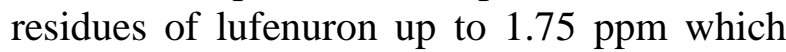

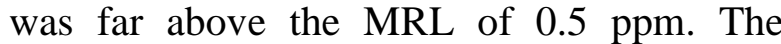

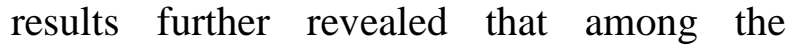

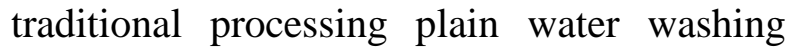

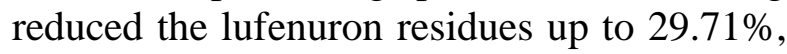

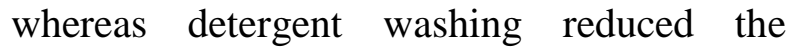

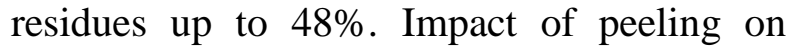

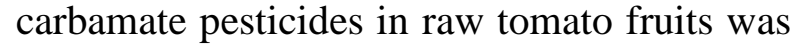

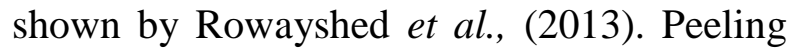

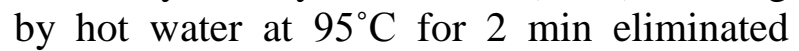

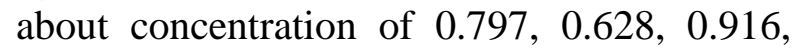

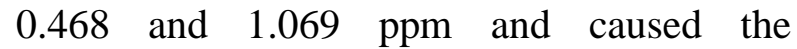

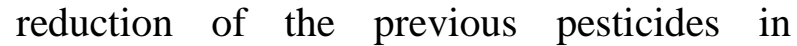

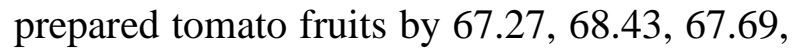

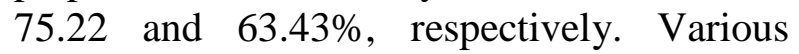

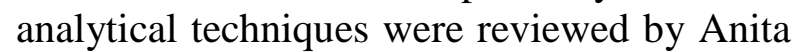

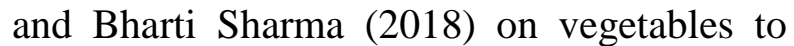

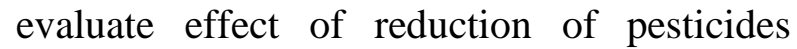

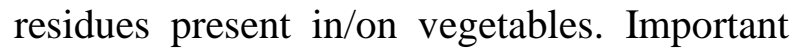

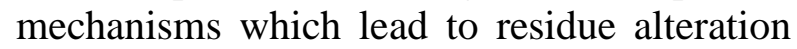

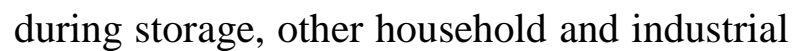

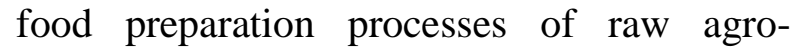

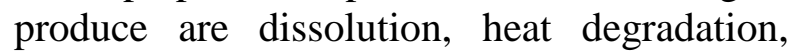

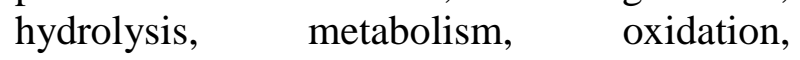

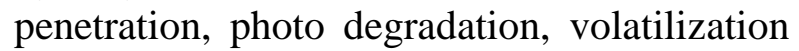

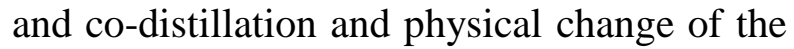

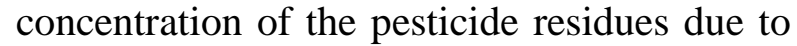

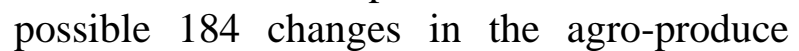

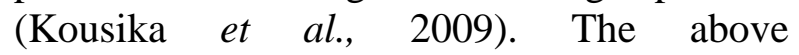

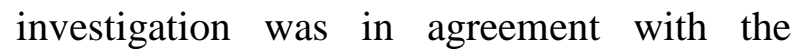

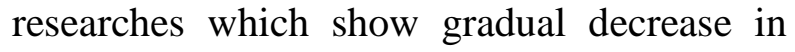

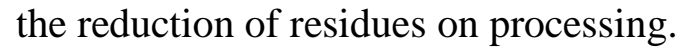

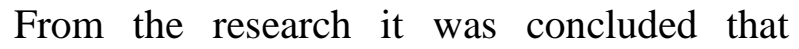

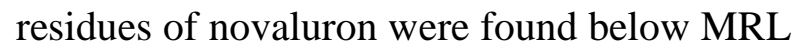

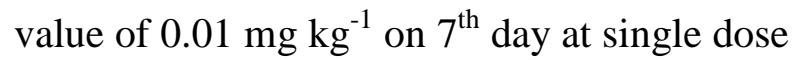


and on $10^{\text {th }}$ day at double dose. Residues of novaluron decreased substantially during household processing among which peeling was found most effective which resulted $80 \%$ reduction.

\section{References}

Anita and Bharti Sharma, 2018. Review on Analytical Techniques used for the Estimation and Persistence of ReadyMix Formulation Residues in Various Crops and Soil. International Journal of Science and Research (IJSR), Volume 7(3), 78 - 81.

Claeys, W. L., Schmit, J. F., Bragard, C., Maghuin-Rogister G., Pussemier, L. and Schiffers, B. 2011. Exposure of several Belgian consumer groups to pesticide residues through fresh fruits and vegetable consumption. Food Control, 22 (3-4), 508-516.

Das, P., Pal, R. and Chowdhury, A. 2007. Dissipation of novaluron in chilli and brinjal. Journal of Entomology, 4, 163 166.

Das, P., Pal, R. and Chowdhury, A. 2008. Influence of biotic-abiotic factors on the degradation of novaluron in tropical soil. International Journal of Environmental Science and Technology, 5 (3), 425-429.

Ganesan, M., Rajesh, M., Solairaj, P. and Senthilkumar, T. (2012). Tomato as a pioneer in health management.

International Journal of
Pharmaceutical, Chemical and Biological Sciences, 2 (3), 210-217.

Gupta, S., Gajbhiye, V. T., Sharma, R. K., and Gupta, R. K. 2011. Dissipation of cypermethrin, chlorpyriphos, and profenofos in tomato fruits and soil following application of pre-mix formulations. Environmental monitoring and assessment, 174 (1), 337-345.
Kaushik, G., Satya, S. and Naik, S. N. 2009. Food processing a tool to pesticide residue dissipation- A review. Food Research International, 42, 26-40.

Kong, Z., Dong, F., Xu, J., Liu, X., Zhang, C., Li, J., Li, Y., Chen, X., Shan, W. and Zheng, Y. 2012b. Determination of difenoconazole residue in tomato during home canning by UPLC-MS/MS. Food Control, 23, 542-546.

Kong, Z., Shan, W., Dong, F., Liu, X., Xu, J., Li, M. and Zheng, Y. 2012a. Effect of home processing on the distribution and reduction of pesticide residues in apples. Food Additives and Contaminants, 29 (8), 1280-1287.

Kousika J, Kuttalam S, M. and Ganesh Kumar 2017 Evaluation on the effect of tetraniliprole $20 \mathrm{SC}$, anew chemistry of pyridine derivative to the rice arthropod biodiversity. Journal of Entomology and Zoology Studies 5(4), 133-143.

Krol, W. J., Arsenault, T. L., Pylypiw, H., Incorvia and Mattina M. J. 2000. Reduction of pesticide residues on produce by rinsing. Journal of Agriculture and Food Chemistry, 48, 4666-4670

Malhat F, El Sharkawi H, Loutfy N. and Ahmed M. 2014a. Field dissipation and Health hazard Assessment of Fenhexamid on Egyptian Grapes. Toxicological and Environmental Chemistry, 96 (5), 722-729.

Malhat F, Watanabe H. and Youssef A. 2015. Degradation profile and safety evaluation of methomyl residues in tomato and soil. Health and Plant Protection Journal, 8 (2), 55-62.

Malhat, F. M., Loutfy, N. M., and Ahmed, M. T. 2014b. Dissipation kinetics of novaluron in tomato, an arid ecosystem pilot study. Toxicological and Environmental Chemistry, 96 (1), 4147. 
Mirani, B. N., Sheikh, S.A., Nizamani, S. M. and Mahmood, N. 2013. Effect of household processing in removal of lufenuron in tomato. International Journal of Agricultural Science and Research, 3, 235-244.

National Horticulture Board Database, India (2015). Available at: http://nhb.gov.in/areapro/NHB_Databas e_2015.pdf [Accessed 27 Mar. 2016].

Rowayshed, G., Asraf, M.M.S. and Mahmoud, M.M. 2013. Stability of carbamate pesticides residue in some vegetables throughout the household processing and cooking. Middle East Journal of Applied Sciences, 3(4), 205215.

Sheikh, S.A., Panhwar, A.A., Mirani, B.N. and Nizamani, S.M. 2014. Effectiveness of traditional processing techniques on residual removal in chilies sprayed with various pesticides. Journal of Biodiversity and Environmental Sciences, 5(4), 365-370.
Tasei, J. N. 2001. Effects of insect growth regulators on honey bees and non - Apis bees. A review. Apidologie, 32, 527545.

Thamburaj, S. and Singh, N. 2015. Vegetables, tuber crops and spices. Directorate of Knowledge Management in Agriculture, Indian Council of Agriculture Research, Pusa, New Delhi. $469 \mathrm{p}$

Tomer, V. and Sangha, J. K. 2013. Vegetable processing at household level: Effective tool against pesticide residue exposure. IOSR Journal of Environmental Science, Toxicology and Food Technology, 6(2), 43-53.

USEPA, 2017. Conventional reduced risk pesticide program. United States Environmental Protection Agency. Complete URL (https://www.epa.gov/ pesticideregistration/conventionalreduced-risk-pesticide-program) (accessed 1April 2017).

\section{How to cite this article:}

Anita, V. K. Madan, Reena Chauhan and Beena Kumari. 2018. Dissipation Behaviour and Effect of Different Decontamination Processes on Reduction of Residues of Novaluron in Tomato (Lycopersicon esculentum Mill.). Int.J.Curr.Microbiol.App.Sci. 7(05): 648-656. doi: https://doi.org/10.20546/ijcmas.2018.705.079 